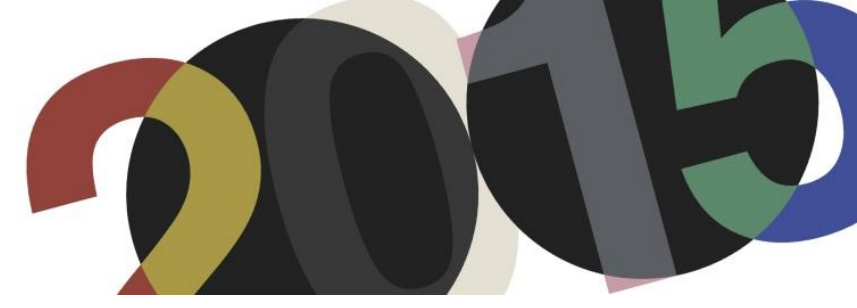

DOI: http://dx.doi.org/10.4995/LC2015.2015.495

\title{
Listening and the League of Nations: Acoustics Are the Argument
}

\author{
S. von Fischer
}

Senior Researcher, Ecole Polytechnique Fédérale de Lausanne (EPFL)

\begin{abstract}
In the debates following the 1926-27 competition for the new headquarters of the League of Nations in Geneva, the acoustic aspect was largely overlooked. The competition coincided with the formation of architectural acoustics as a profession and an academic discipline. Looking at this coincidence sheds new light on the reasoning of Peter Meyer and Sigfried Giedion, who, in support of Le Corbusier and Pierre Jeanneret's scheme, gave remarkable prominence to arguments about acoustics. The transmission of speech in the large Assembly Hall with seating for 2,700 could not be resolved by traditional techniques, and opinions on the modern method of electroacoustic amplification differed greatly. The protagonists who stepped forward in favor of Le Corbusier and Pierre Jeanneret's scheme, for which Gustave Lyon served as acoustic advisor, emphasized the sound quality of their design for the large Assembly Hall. Despite the acoustically infeasible competition brief, they declared literal understanding, based on the intelligibility of speech, to be a fundamental function of the League of Nations headquarters.
\end{abstract}

The questions raised in this paper relate to architecture's aurality and visuality, as well as claims concerning function in debates on Modernism. Diplomatic understanding was evidently at stake in the League of Nations' political program, but, curiously, literal understanding was neglected in the acoustic design for the Assembly Hall by many of the competitors and the jury, and - apart from a short remark by Jacques Gubler in 1985 - was subsequently overlooked by historians.

Keywords: acoustics; function; functionality; League of Nations; Gustave Lyon; Franz Max Osswald.

\section{Introduction: Understanding at the League of Nations}

This paper revisits the arguments following the 1926-27 competition for the headquarters of the League of Nations in Geneva, often referred to as the Palace of the League of Nations. While the architects were concerned with looking at the plans and elevations, at the stage of the competition many of them largely overlooked the projects' acoustical feasibility, which would come to play a prominent role in the assembly hall's technical performance, as well as in the protagonists' rhetoric and Modernism's claims to functionality: “The design they [Le Corbusier and Pierre Jeanneret] had submitted was essentially one for a place to work in, corresponding to contemporary requirements. It incorporated entirely new technical solutions in the Office Wing, an acoustically perfect Assembly Hall,"1 as the authoring architects themselves stated in the first volume of the Euvre Complète.

Le Corbusier and Pierre Jeanneret's scheme was designed using state-of-the-art technologies, both in the acoustical design of the auditorium for the large Assembly Hall, which drew on advice from Gustave Lyon, as I will explain in this paper, and in the communication equipment for the offices, where electroacoustic apparatuses were devised. When investigating the hall's acoustical feasibility more closely, elemental questions relating to the nature of Le Corbusier's approach to architecture's performance as a place "to work in" remain to be

\footnotetext{
${ }^{1}$ Le Corbusier: Le Corbusier et Pierre Jeanneret. Euvre Complète de 1910- 1929. Zurich: Girsberger, 1937, p. 161 (original emphasis).
} 
answered. Why did Sigfried Giedion, who was never shy to embrace new technologies, argue in 1927 that loudspeakers were not feasible to amplify the speeches in the Assembly Hall? ${ }^{2}$ In the same year, acoustic scientists successfully enhanced the volume of speech in the Cologne Cathedral by using large loudspeaker systems. $^{3}$

Much has been written about the heated debates in the battle over styles, over historicist and functionalist architectures, 4 over "les académies" and "les autres,"5 and over claims for and against monumentality. It is the hypothesis of this paper that the modern science of architectural acoustics provided a telling argument in the debates following the League of Nations competition results. I will show that expertise in architectural acoustics and arguments advocating a "functional" Palace of Nations entered a mutually empowering coalition. In the debates over the League of Nations competition entries, focusing on acoustics helps us understand the instrumentalization - and at the same time the fundamental importance-of function in architecture. These architectural discourses on function addressed not functionality per se but a performance, projected onto an architectural program and driven by an aesthetic agenda.

\section{A Function Overlooked}

Understanding was at the core of the agenda at the League of Nations. Founded in the aftermath of World War I, the League was created to ensure international security, world peace, and understanding between all nations. The competition launched in March 1926 attracted 377 teams of architects, who delivered a total of more than 10,000 panels in January 1927. After long discussions, the jury awarded 27 projects out of the 377 with nine first prizes, nine first mentions, and nine second mentions. ${ }^{6}$ Before the jury gathered, its members had been alerted to the unrealistic challenge that had been set in terms of the General Assembly's acoustics. ${ }^{7}$ In the unusually large auditorium for 2,675 people, the spoken words would hardly be audible in the rear areas. It was therefore not only political, but also acoustic understanding that was at stake in the designs for the League of Nations' large

\footnotetext{
${ }^{2}$ Giedion, Sigfried: “Wer baut das Völkerbundgebäude?” Bauwelt, 18, № 44 (November 3), 1927, p. 1094. I am indebted to Gregor Harbusch, who in the early years of my dissertation shared his puzzlement over Giedion's remark on loudspeakers.

${ }^{3}$ Electroacoustics pioneer Ferdinand Trendelenburg wrote that such large loudspeakers worked well in free-field conditions, but that many enclosed spaces, especially those with excessive sound reflections (“Überakustik") remained a challenge. Ferdinand Trendelenburg: "Über Bau und Anwendung von Grosslautsprechern" in Elektrotechnische Zeitschrift, 48, 1927, p. 1691. My thanks to Roland Wittje for directing me to this source.

${ }^{4}$ It is important to differentiate the term "Functionalism" as an architectural style, which was not in use until the postwar era and is often regarded as originating in Louis Sullivan's dictum "form follows function," from Behne's 1926 "Zweckbau."

${ }^{5}$ Terminology used by Le Corbusier when comparing his cost estimates of 27/30/40/50 m respectively, for the four projects chosen by the League of Nations' jury, with the calculation of his own project at $12.5 \mathrm{~m}$. Figure 94 in Frampton, Kenneth: "Le Corbusier and 'l'Esprit Nouveau." Oppositions, № 15/16 (Winter/Spring), 1979, p. 46.

${ }^{6}$ For a detailed account of the competition processes and politics, see Ritter, John: "World Parliament. The League of Nations Competition, 1926." Architectural Review, $\mathrm{N}^{\circ} 136$ (July), 1964. pp. 17-23 (a study motivated by Colin Rowe at the Cambridge School of Architecture); Moos, Stanislaus von: Le Corbusier. Elemente einer Synthese. Frauenfeld: Huber, 1968. pp. 227 ff; Oechslin, Werner; Roth, Alfred: Le Corbusier \& Pierre Jeanneret: Das Wettbewerbsprojekt für den Völkerbundspalast in Genf 1927: à la recherche d'une unité architecturale. Zurich: gta Verlag, 1988 (with a reprint of the Swiss report of experts on behalf of the jury); Pallas, Jean-Claude: Histoire et architecture du Palais des Nations (19242001). L'Art déco au service des relations internationales. Geneva: Nations Unies, 2001 (an illustrated book commissioned by the UN, documenting primarily the history of the building by architects Nenot and Flegenheimer, together with Vago, Boggi, Vacaro, Franzi, and Lefevre).

${ }^{7}$ Letter from Ritter on behalf of the jury, ETH Zürich, gta archive: 33-JGS-1926/27 (provisional numbering code), Nachlass Karl Moser, Hängeregister Völkerbundpalast, Juryberichte.
} 
Assembly Hall. This dimension was, curiously, suppressed both in the competition brief and in many of the competitors' projects, and subsequently overlooked by historians.

In Schweizerische Bauzeitung of July 30, 1927, and in The American Architect of December 20, 1928, the acoustic quality of the architectural projects for the General Assembly's hall was discussed over eight and ten pages respectively. The author of both articles was Switzerland's first expert in architectural acoustics and the founder of the country's first applied acoustics laboratory at an academic institution, E.T.H. in Zurich: Franz Max Osswald. Both his publications prominently featured Le Corbusier and Pierre Jeanneret's scheme as the most feasible, based on the relatively small — though still too large_volume of 40,000 cubic meters and the favorable geometry of the plan, with no parallel walls and a ceiling shaped to reflect sound throughout the large Assembly Hall. These two publications, with a few others, were the basis on which E.T.H. granted Osswald his permission to teach at university level, the venia legendi, in 1929. That was also the year when the Acoustical Society of America held its first meeting and published the first issue of its journal. The year 1929 thus stands for the formation of the academic discipline of acoustics, both in the microhistory of Osswald's career in Switzerland and in the global history of acoustic sciences. ${ }^{8}$

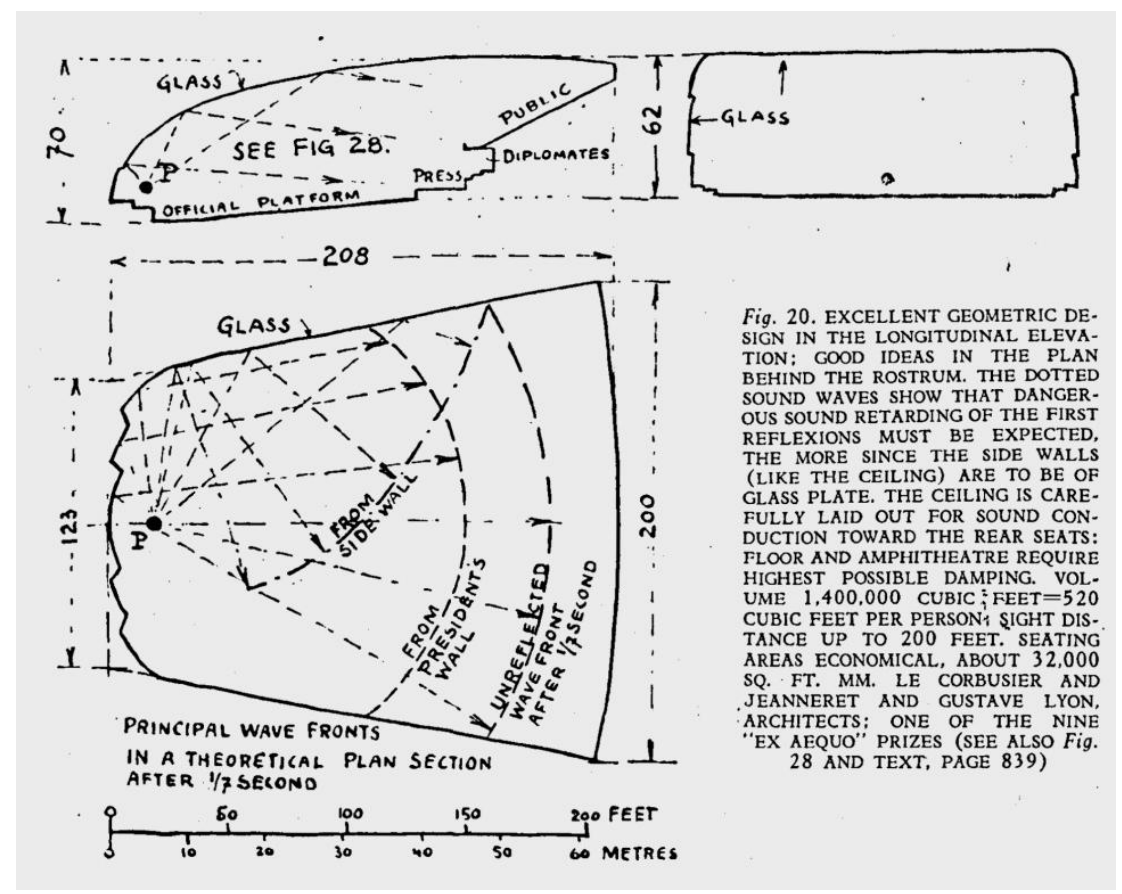

1. Franz Max Osswald's analysis of the acoustic performance of the large Assembly Hall in Le Corbusier and Pierre Jeanneret's proposal to the League of Nations. The American Architect, December 20, 1928.

Osswald's reasoning on the Assembly's acoustics, like most of his methods, took account of reverberation time as established by the Harvard physicist Wallace Clement Sabine ${ }^{9}$ around $1900 .{ }^{10}$ The reverberation formula

\footnotetext{
${ }^{8}$ Osswald, Franz M.: Schall und Raum. Antrittsrede an der Eidgenössischen Technischen Hochschule in Zürich, 29. Juni 1929. Zurich: E.T.H., 1929. For a longer history of Osswald's career, see Fischer, Sabine von: Das akustische Argument. Zurich: gta Verlag (in preparation).

${ }^{9}$ Sabine, Wallace C.: Collected Papers on Acoustics. Cambridge, MA: Harvard University Press, 1922.

${ }^{10}$ Emily Thompson's benchmark historiography has done a great deal to mark the year 1900 as the founding moment of modern architectural acoustics. Thompson, Emily: The Soundscape of Modernity. Architectural Acoustics and the Culture of Listening in America, 1900-1933. Cambridge, MA: MIT Press, 2002.
} 
calculates the time that a sound signal takes to pass the human ear's hearing threshold at zero decibel. If the duration is too short, the sound is considered "dead" or "dry," but this mostly applies to concert halls and is seldom considered problematic elsewhere. Much more often, and especially in the case of halls for speech, the reverberation time may be too long, and the words spoken cannot be understood. Such long reverberation times, or echo, may be desirable for chants in a Gothic cathedral; in the auditorium for the assembly of the League of Nations delegates, where international understanding lay at the heart of the program, it was not.

According to the reverberation formula " $\mathrm{T}=0.16 \mathrm{~V} / \mathrm{A}$," which is still in use today, the reverberation time is calculated proportional to the volume of the space, and reversely proportional to the absorbing capacity of the materials. As a sketch for the archive shows, Le Corbusier and Pierre Jeanneret calculated the volume per person in the auditorium. The total number of persons required by the competition brief to be seated in the Assembly Hall added up to 2,675; this number resulted from the program requirements, which listed a party of 25 speakers at the center of the podium (including the president, secretary general, and interpreter), 400 delegates, 400 secretaries, 250 diplomats, 600 journalists, and an audience of 1,000.

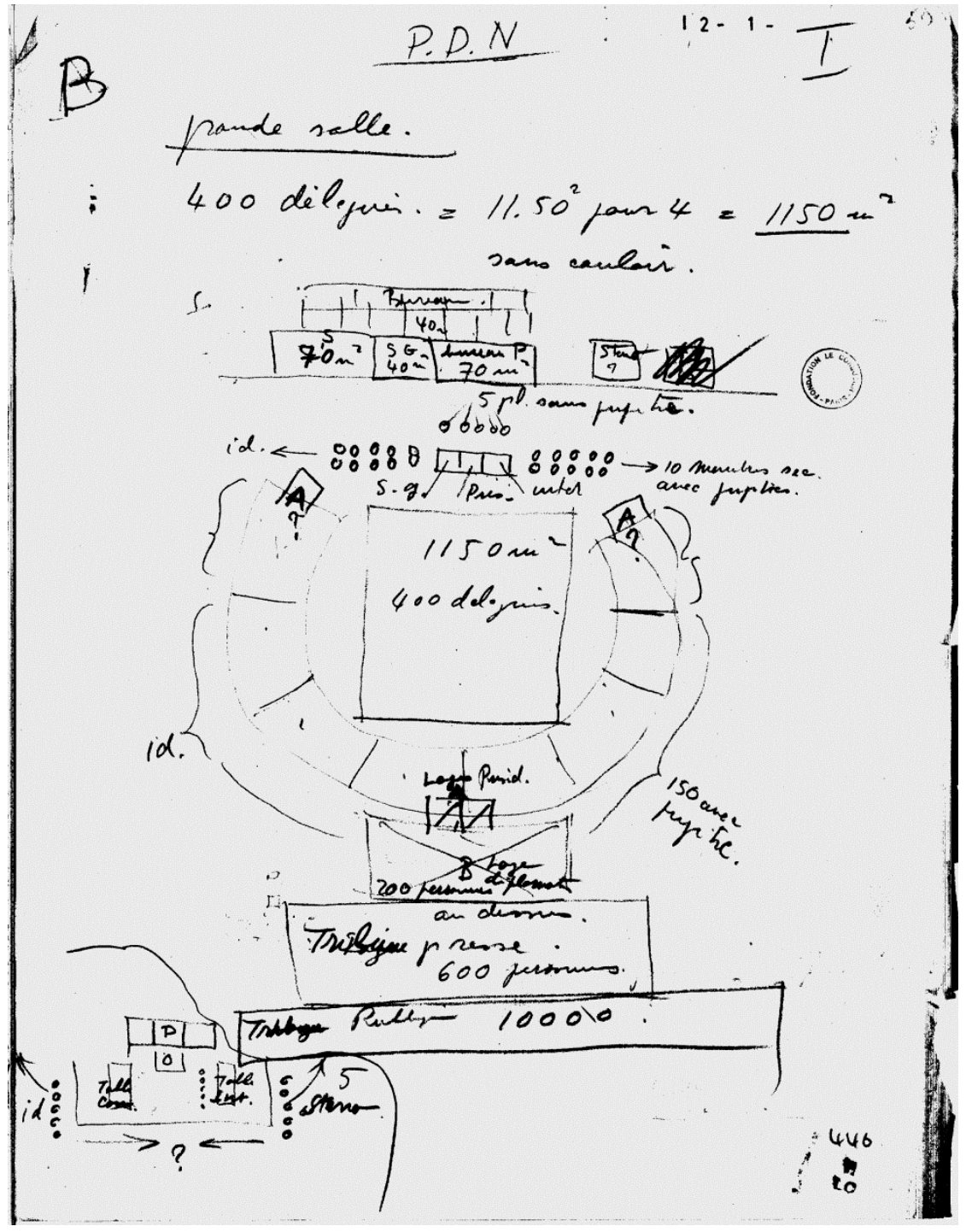

2. Le Corbusier and Pierre Jeanneret's study for the General Assembly's layout for 2,675 people. 

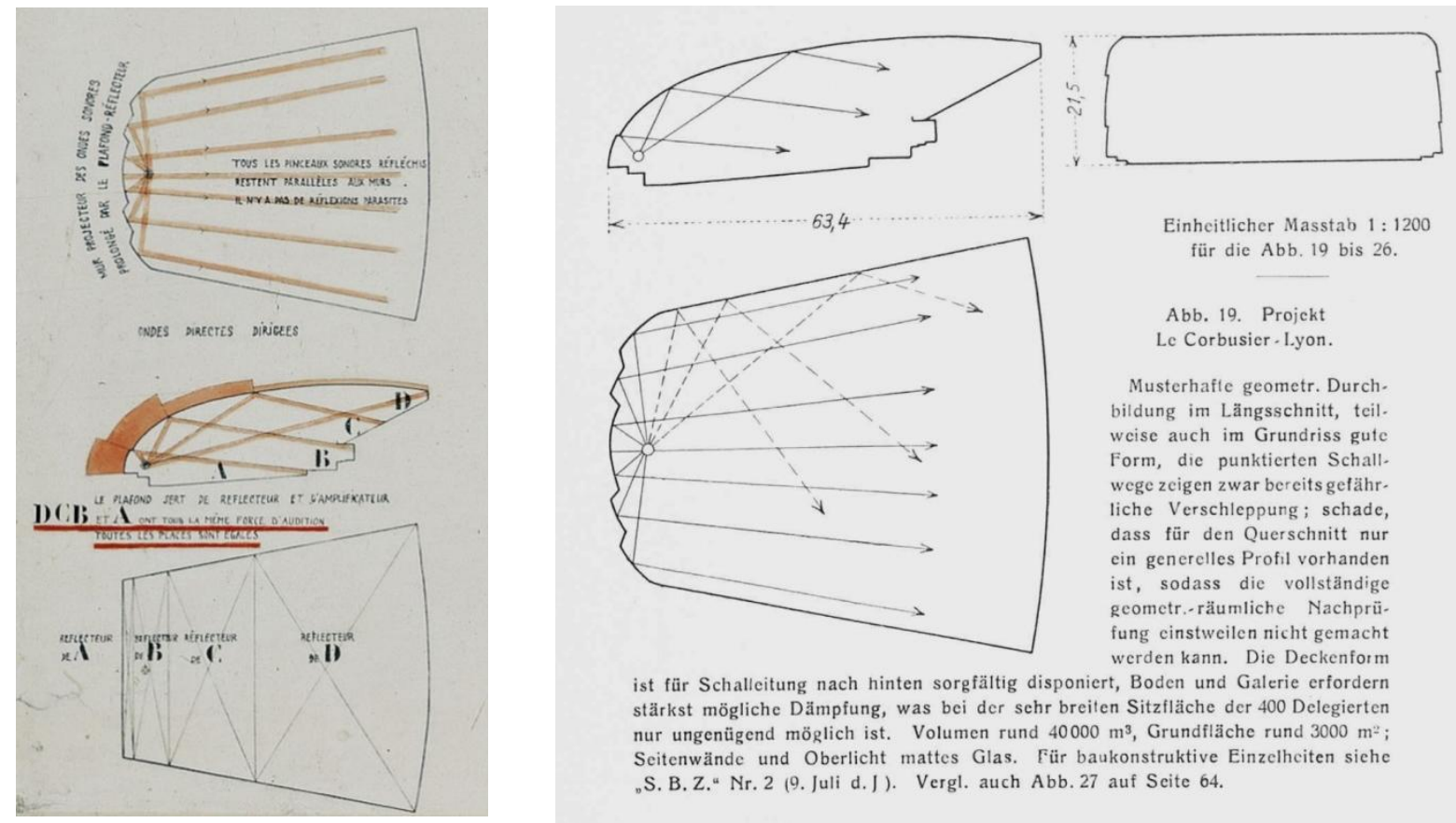

3 - 4. Detail of the acoustic principles on the competition panel and in Schweizerische Bauzeitung.

On panel 10 of Le Corbusier and Pierre Jeanneret's competition entry, showing the plan of the large Assembly Hall in the center, the acoustical design is explained in the lower left-hand corner. Sound is understood as wave fronts which are directed from the speakers into the audience by the architectural elements:

"Ondes directes dirigées:

Mur projecteur des ondes sonores prolongé par le plafond-réflecteur.

Tous les pinceaux sonores réfléchis restent parallèles aux murs. Il n'y a pas de réflexions parasites.

Le plafond sert de réflecteur et d'amplificateur.

D C B et A ont tous la même force d'audition.

Toutes les places sont égales."

The schematic drawing of the sound wave reflections from the ceiling into all areas of the audience equally was copied from the competition panels into Franz Max Osswald's Schweizerische Bauzeitung article of July 30, 1927, which had praised the acoustical design by "Lyon - Le Corbusier." In the issue of July 9, soon after the publication of the jury report on May 5 in which nine projects were awarded a first prize ex aequo (followed by nine first and nine second mentions), editor Peter Meyer had written a fierce commentary. Meyer's attack on the "pompuous gestures of the monumental palaces" 12 was a fiery introduction to the following pages, in which Le Corbusier and Pierre Jeanneret's project was published in extenso, though with only marginal mention of the acoustical aspects. These were discussed on three weeks later, on July 30, when another eight pages dedicated to the controversial competition focused on Le Corbusier and Pierre Jeanneret's project, this time with special attention to the Assembly Hall's acoustics. In this second review, "Zum Problem der Akustik im grossen Versammlungs-Saal des Völkerbund-Gebäudes in Genf" (On the Problem of Acoustics in the Large Assembly Hall of the League of Nations Building in Geneva), Osswald spent ample time inveighing against many projects' large volumes of up to 260,000 cubic meters and dome structures where echos would render any speech

\footnotetext{
${ }^{11}$ ETH Zürich, gta archives: Völkerbundpalast, Le Corbusier, 185-01-10.1.

12 Meyer, Peter; Le Corbusier: "Internationaler Wettbewerb für das Völkerbund-Gebäude in Genf." Schweizerische Bauzeitung, 90, No 2 (July 9), 1927, p. 13.
} 
unintelligible. In the article, function is emphasized to the point of becoming a rhetoric, and we can only assume that, as editor, Peter Meyer was instrumentalizing Franz Max Osswald's scientific expertise in the service of his own Modernist propaganda. In a single sentence, Osswald's text refers to function (in German: "Zweck," “Zweckmässigkeit”) three times. ${ }^{13}$ Le Corbusier and Pierre Jeanneret's scheme was the only one to receive any praise for its acoustical design in the article. Nevertheless, Osswald still considered its 40,000 cubic meters to exceed the ideal auditorium volume of 10,000 , or at most 20,000, cubic meters.

Auditorium geometries where sound was reflected and directed primarily by the ceiling were a standard feature of architectural handbooks around 1930, and Osswald himself experimented with architectural geometries, for example in his own hors concours proposition for an Assembly Hall for the League of Nations (see Fig. 17, lower right). He also experimented with models of an "auditorium with variable volume"14 for which he built both a large presentation model and an acoustic study model. The images produced from these models followed Wallace C. Sabine's examples, which employed a technique adapted from schlieren photography. ${ }^{15}$
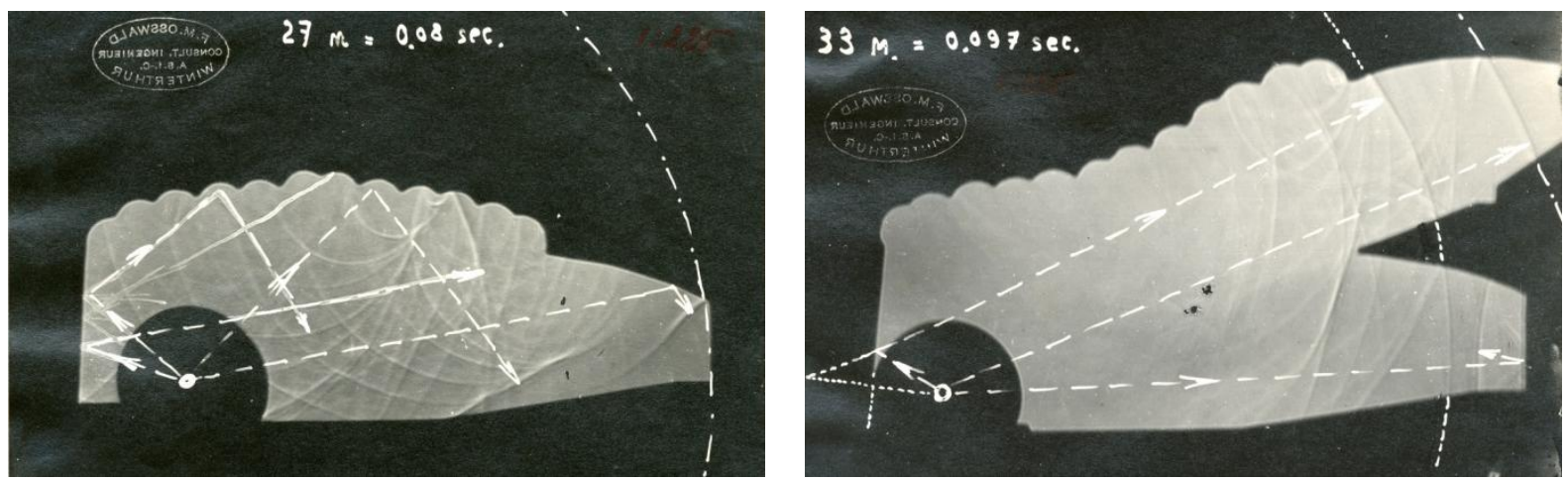

5 - 6. Osswald's photographic experiments for an auditorium of variable size in 1930.

7. Osswald's laboratory for applied acoustics at ETH Zurich.

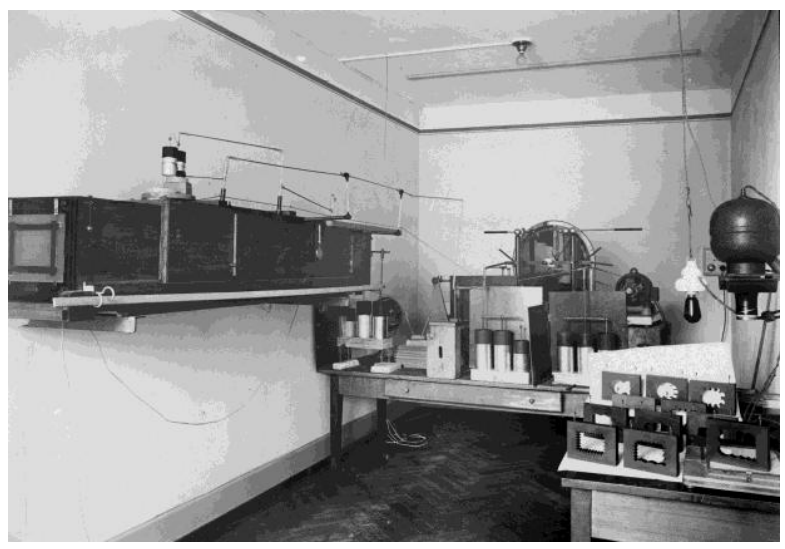

\footnotetext{
13 “der Architekt hat nun die Wände, Decken und Galerien zu einer zweckmässigen und schönen Form aufzubauen, wobei wir bewussterweise die Zweckmässigkeit voranstellen, denn, um nocheinmal daran zu erinnern, Verständigung ist doch der Endzweck!" (emphasis added). Osswald, Franz M.: “Zum Problem der Akustik im grossen Versammlungs-Saal des Völkerbund-Gebäudes in Genf.” Schweizerische Bauzeitung, 90, № 5 (July 30), 1927, p. 59.

${ }^{14}$ Osswald, Franz M.: “Akustischer Konzert- und Vortragsaal mit veränderlichem Volumen.” Schweizerische Bauzeitung, 96, $\mathrm{N}^{\circ} 18$ (November 1), 1930, pp. 224-225.

15 Sabine, Wallace C.: "Theatre Acoustics." The American Architect, 104, No 1984, 1913, pp. 256-278. For more on Osswald's architectural sound photography, see von Fischer, Sabine: “A Visual Imprint of Moving Air” (in preparation).
} 


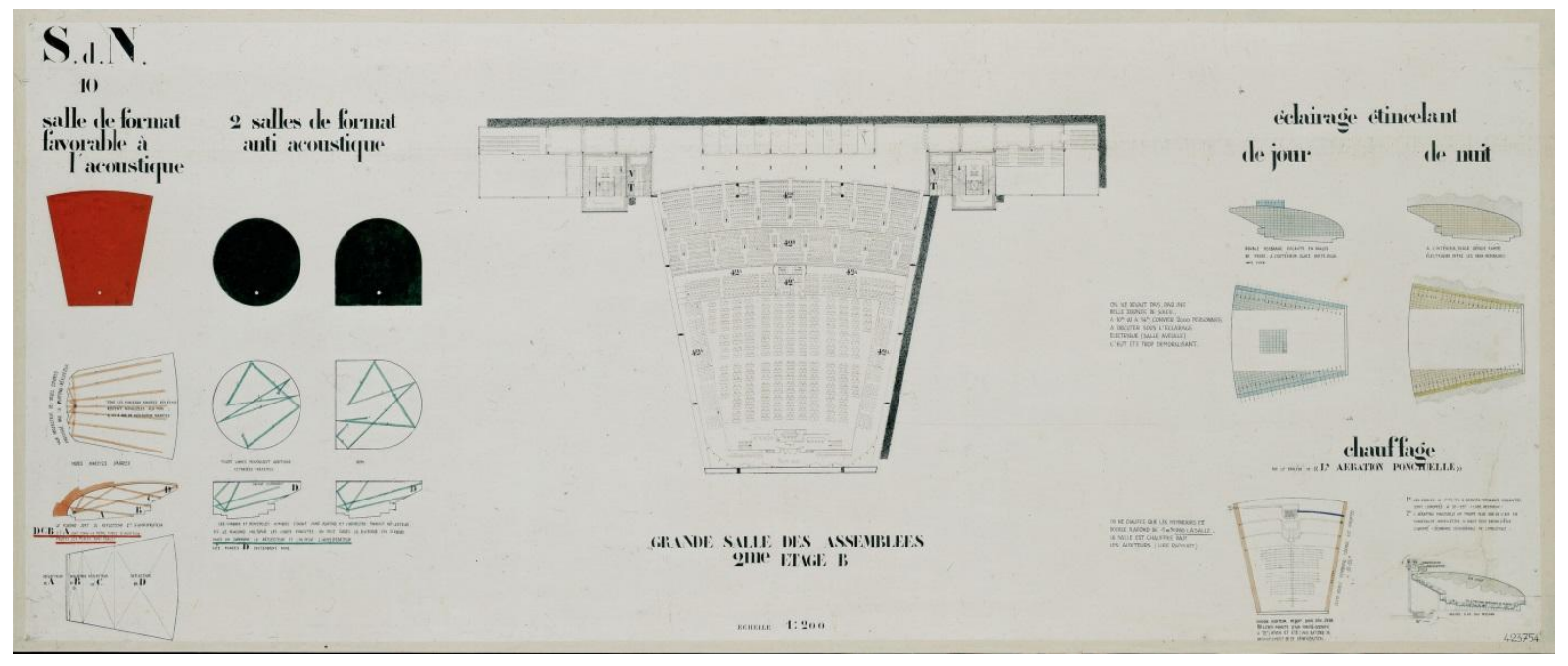

\section{Directing Sound}

Few of the competitors articulated their solutions for the auditorium's acoustics as explicitly as Le Corbusier and Pierre Jeanneret did in their graphic presentations. The panels were clearly didactic, placing their own auditorium plan next to a diagrammatic explanation — in bright and bold red letters — of the "salle de format favorable à l'acoustique." In counterpart, a circular and a semicircular shape were boldly, in black lettering, said to be " 2 salles de format anti acoustique"; ${ }^{16}$ such shapes (and this was not difficult to predict) occurred in many of the competition entries. Symmetrical plans with curved walls were a typical nineteenth-century solution for auditoriums and derived from the auditorium's precursor, the Greek amphitheater. For Le Corbusier, however, amphitheaters belonged to a completely different typology, being open to the sky.

Le Corbusier and Pierre Jeanneret relied on completely different references, those of modern architectural acoustics. They were advised by Gustave Lyon, a French engineer who had made a name for himself as director of the Parisian piano manufacture Maison Pleyel. As the director of Pleyel, Lyon devised a concert hall according to the laws of directed sound, calculating the time it took sound to travel from the orchestra to the audience. The ceiling was parabolically curved and low enough to prevent overly long delays between the direct sound and the reflected sound, which would be desirable neither with regard to the intelligibility of the spoken word nor to the clarity and distinctness of musical sound.

Lyon's internationally acclaimed design for the Maison Pleyel concert hall became a model for parabolic ceiling geometry in auditoriums. However, as the sound traveled not only from the podium to the audience but vice versa, it disturbed both the musicians and the music itself. The rear of Salle Pleyel wall was therefore, after its first remodeling, lined with absorbent Molleton. Photos, plans, and sections of the concert hall were published internationally, in the state with the absorbent rear lining. On July 18, 1928, the highly flammable Molleton caught fire, ${ }^{17}$ and a young American died. In view of this tragedy, Gustave Lyon addressed a personal letter to Le Corbusier on July 21 expressing his regret and saying that the repair would be undertaken "without delay."18

\footnotetext{
${ }^{16}$ ETH Zürich, gta archives, Völkerbundpalast, Le Corbusier, 185-01-10.1.

${ }^{17}$ Osswald, Franz M.: “Akustisch hochwertige Parabelsäle.” Schweizerische Bauzeitung, 95, № 4, 1930, pp. 47-51.

${ }^{18}$ Lyon to Le Corbusier (“Mon cher ami”), July 21, 1928, FLC Correspondences: LYON, GUSTAVE, 64-70: E2-9-65-001.
} 


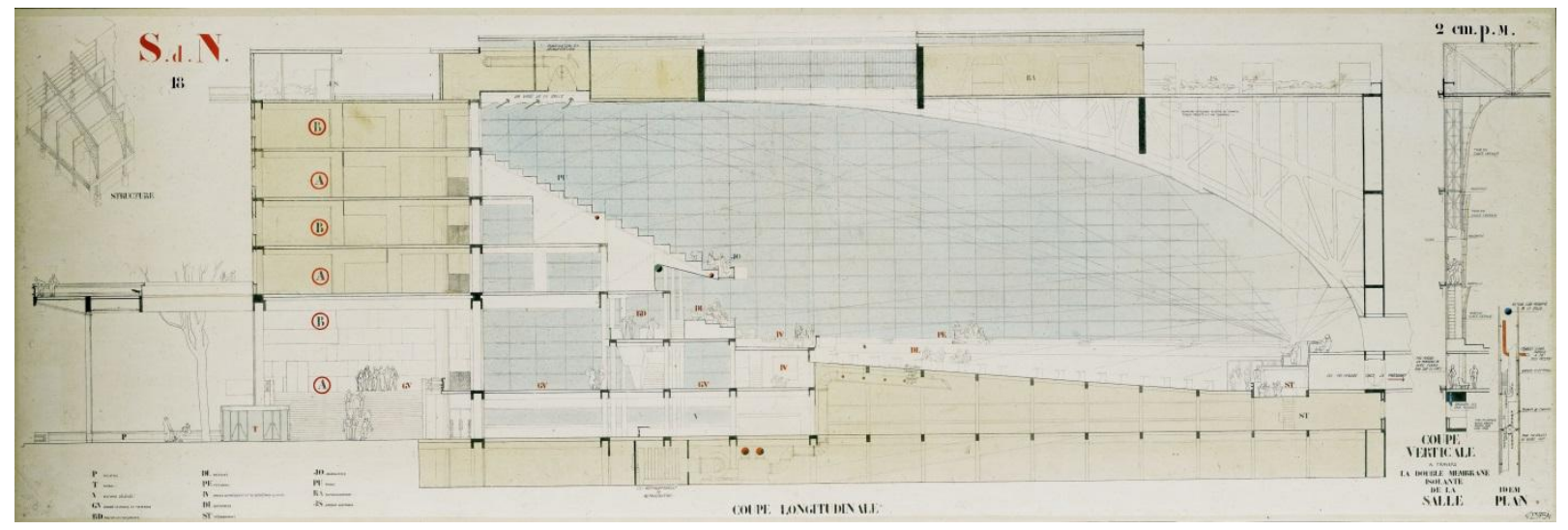

8 - 9. Le Corbusier and Pierre Jeanneret's competition panels 10 and 14.
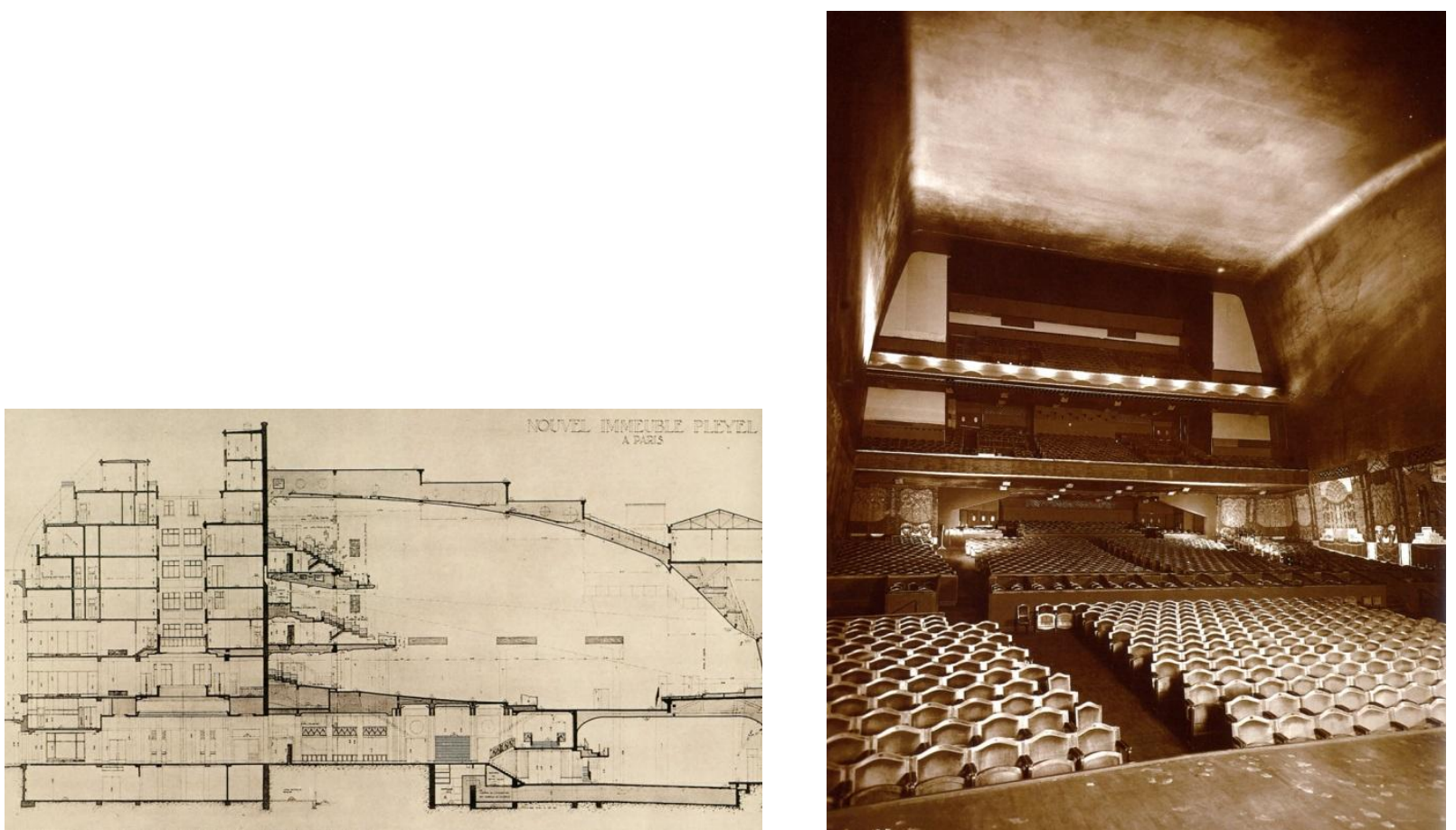

10 - 11. Section of Salle Pleyel by Gustave Lyon; Interior of Salle Pleyel, 1927.

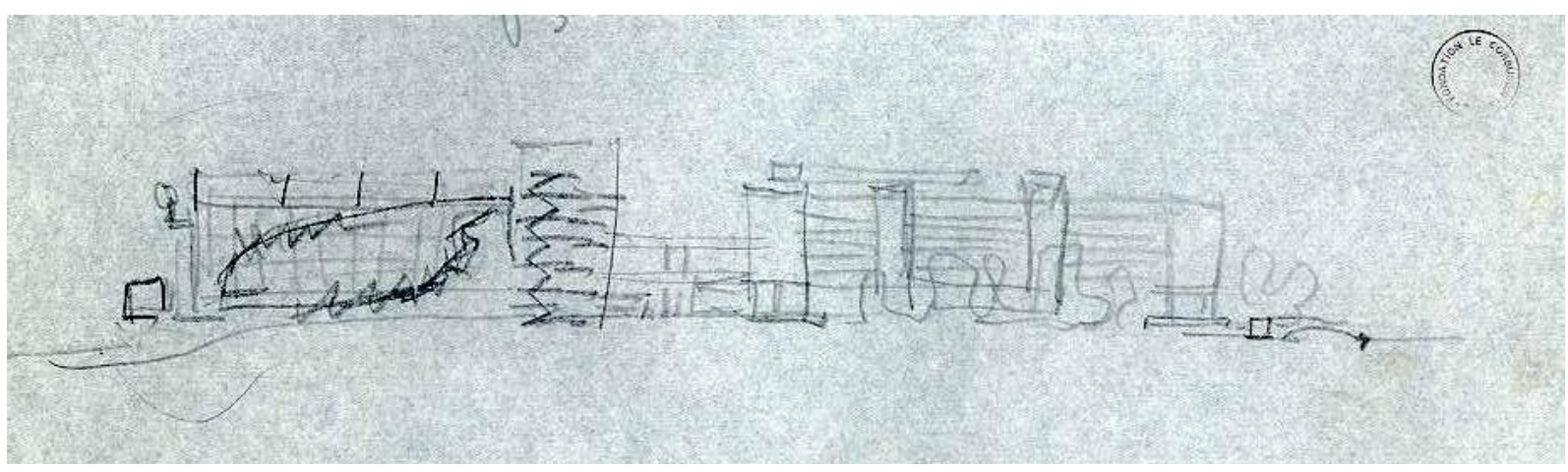

12. Section of Le Corbusier and Jeanneret's large hall for the General Assembly (1927). 


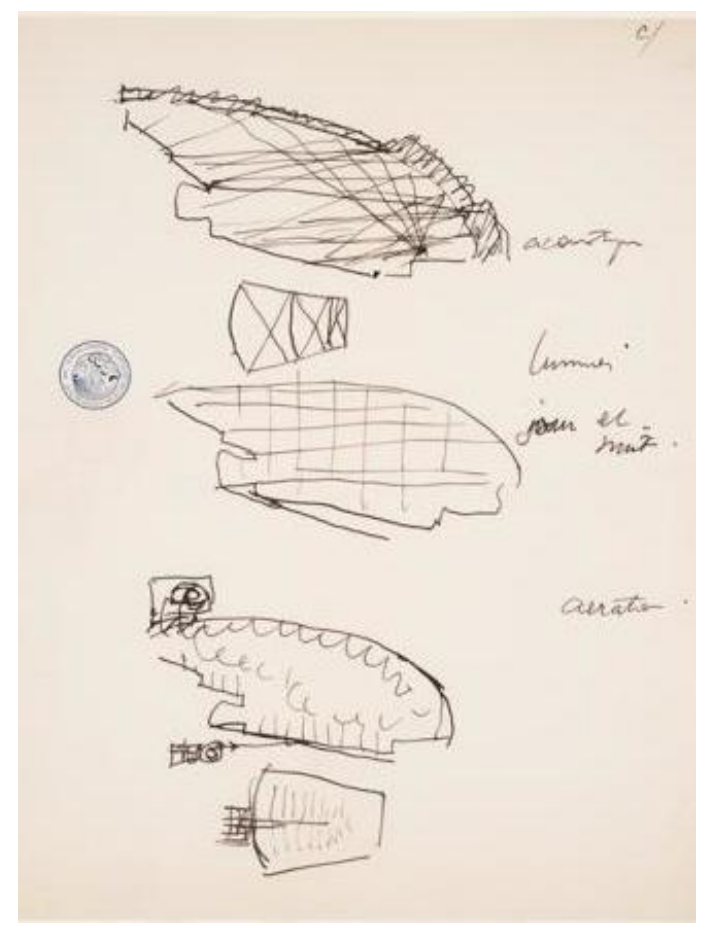

13. Sketch explaining acoustics, lighting, and ventilation of the large hall for the General Assembly (1929).

Correspondence between Gustave Lyon and the atelier of Le Corbusier is documented from 1927 until $1935,{ }^{19}$ the year before Lyon's death. According to Alfred Roth's oral account, as passed on by Gubler und Quincerot, ${ }^{20}$ Lyon visited Rue Sèvres to give his acoustical consultations. Even more telling are the journals, newspaper clippings, and letters in the archive in which Le Corbusier and Gustave Lyon expressed their mutual admiration:

\begin{abstract}
"Mon cher ami Le Corbusier,
je viens de recevoir votre lettre contenant le chèque de $80 \mathrm{f}$ que je vous retourne, car il n'a jamais été fait état de cette recette, puisque vous étiez notre délégué expert. Je profite de vos observations si sérieuses pour vous signaler le rôle puissant que vos idées neuves audacieuses et logiques ont pu avoir de la genèse de la conception de la salle de musique. Vous savez combien et dès la première parution de vos conceptions nouvelles j'y ai pris plaisir et porté intérêt.

$C$ 'est vous, pour parti, qui m'avez amené à ne pas m'arrêter en route sous prétexte de vieilles formules à respecter. Et à ne me laisser conduire que par la logique appuyée sur l'éxperience des temps trèspassés. Je vous souhaite de triompher de toutes les difficultés que des jaloux cherchant à semer sur votre route, et vous assurer que j'ai le plus grand désir de vous aider de tout mon faible pouvoir. Croyez, mon cher ami a mes très cordiaux sentiments d'estime et de très sympathique admiration, G. Lyon"
\end{abstract}

\footnotetext{
${ }^{19}$ FLC, Correspondences: LYON, GUSTAVE, 64-70: Correspondance avec L.C. 26/08/1927-09/02/1935.

${ }^{20}$ Gubler, Jacques; Quincerot, Richard: “Da Maratona a Ginevra.” Parametro, No 140 (October), 1985, p. 27, footnote 35: "Intervista con Roth. Roth e assolutamente sicuro che Lyon sia andato all'atelier di L. C." Gubler and Quincerot's essay "From Marathon to Geneva" (in six versions in the archive of the CCA in Montréal) was possibly intended for a 1980 publication in Oppositions 15/16 or 19/20. On editorial and publishing practices and policies in New York architecture circles, see Förster, Kim: The Institute for Architecture and Urban Studies (1967-85). Zurich: gta Verlag (in preparation).
} 


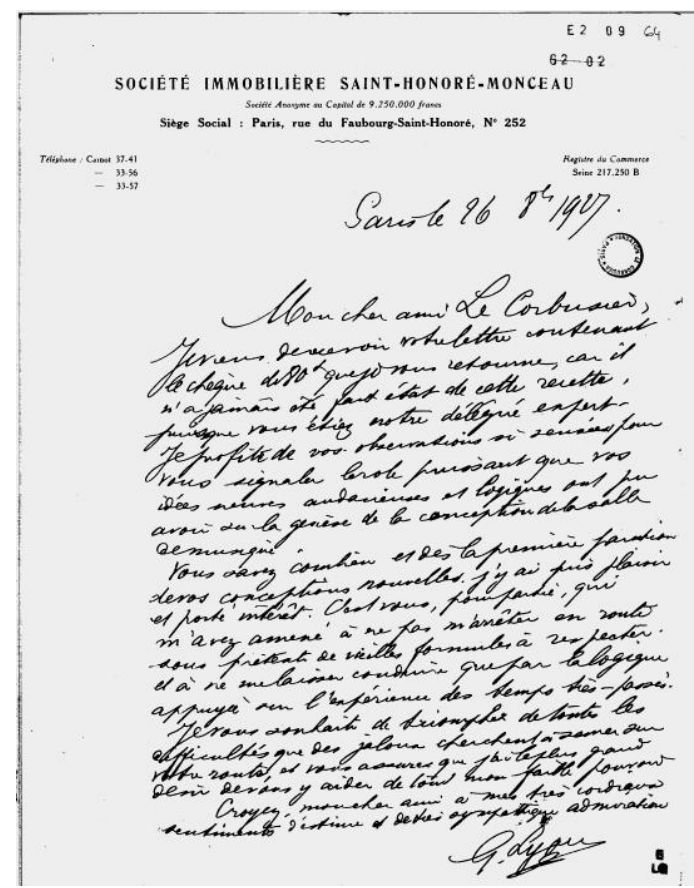

14. Letter from Gustave Lyon to Le Corbusier, August 26, 1927.

Old formulas were to be replaced with new ones, a project on which Le Corbusier and Lyon embarked with enthusiasm. In a letter dated August 26, 1927, ${ }^{21}$ the acoustician called the architect "our expert delegate" and gave him substantial credit for the renewal in architectural acoustics. In return, the architect praised the acoustician on the front page of the evening edition of $L$ 'Intransigeant ${ }^{22}$ of October 15, 1927: “Acoustique: Une conquête de la technique moderne" was a eulogy on Lyon's calculations of the sonic realm by mathematical formula. The laws of statics and dynamics having been recognized a long time ago, it was thanks to Gustave Lyon and his science that acoustics had escaped from the world of mysteries. Now that these acoustic laws had been successfully applied in the Salle Pleyel, wrote Le Corbusier, it would no longer be possible to build a theater as before.

In 1928, Lyon defended Le Corbusier and Pierre Jeanneret's League of Nations competition entry, as part of the vast and vehement public campaign in the course of which the cousins filed a lawsuit against the award of the building commission to a team composed of other prize winners, who, they claimed, had stolen many ideas from their scheme. In a public declaration in the second issue of Cahiers d'Art, Lyon signed the "manifestation des savants, des industriels, des poètes, des financiers en faveur du projet le Corbusier et Pierre Jeanneret",23 jointly with 83 prominent Parisians and international celebrities, among them composers, directors, and writers.

Lyon was not mentioned in the project description in Cahiers d'Art, but his name was all the more prominent on the two following pages: "La Salle Pleyel. Une preuve de l'évolution architecturale" was the title of Le Corbusier's article honoring "le savant directeur de la Maison Pleyel qui vient de sortir victorieux de ses quarante années de recherches." In it, Le Corbusier argued that the "chimera of acoustics" had been vindicated

\footnotetext{
${ }^{21}$ Lyon to Le Corbusier (“Mon cher ami Le Corbusier”), August 26, 1927, FLC Correspondences: LYON, GUSTAVE, 64 70: E2-9-64-001.

${ }^{22}$ Le Corbusier: “Acoustique: Une conquête de la technique moderne.” L'Intransigeant (October 15, 1927), p. 1.

${ }^{23}$ Amundsen, M.M. and others: "Manifestation des savants, des industriels, des poètes, des financiers en faveur du projet le Corbusier et Pierre Jeanneret." Cahiers d'Art, 3, No 2, 1928, p. 87.
} 
by "calculus" and that this new truth could assure the intelligibility of all speeches: "Mais voici qu'aujourd'hui, la salle Pleyel, c'est la vérité aussi, la vérité de fait, la vérité fonctionnante, s'opposant à la vérité factice de l'Institut; et l'Institut s' incline devant cette nouvelle vérité irréfutable. [...] Comment les responsables de la S.D.N. toléreraient-ils qu 'on leur livrât une salle où l'on n'entendrait pas les discours? Et il est à présumer que dans le monde entier, tout futur tenancier de salle exigera le maximum de sécurité acoustique."24

The collaboration lasted. According to Jean-Louis Cohen's study of the Moscow projects, in the 1930 proposal for Moscow Le Corbusier again mentioned Lyon's "science of sound," which promised to "make the housing units completely soundproof." ${ }^{25}$ In 1931, when designing the Palace of the Soviets, Le Corbusier insisted on setting up a contract with Lyon and paying him for his expertise, and even sent him an advance payment. Though, in the final project he combined Lyon's proposal with another Parisian expert's calculations. ${ }^{26}$

Lyon's career, like Osswald's, coincided with the emergence of the discipline of architectural acoustics in the mid-1920s, at the awakening of professionalization and the formation of an academic discipline in 1929. Lyon's own stationery at the beginning of the 1930s presented his expertise elaborately in the letterhead as "ACOUSTIQUE ARCHITECTURALE, ORTHOPHONIE DES SALLES, AERATION DES SALLES, ISOLEMENT PHONIQUES DES SALLES, (SYSTEME GUSTAVE LYON)" and continued in smaller print with applications of soundproofing for offices, apartments, and the outdoors, followed by the description of his professional status as "INGENIÉUR ACOUSTICIEN." ${ }^{27}$ This makes it obvious that, in accordance with the proliferation of architectural acoustics as a professional field and an academic discipline, the director of the Maison Pleyel had expanded and professionalized his acoustic expertise to offices, housing, and urbanism.

\section{Modern Voices and Their Arguments}

Already before Osswald's expert critique of the acoustics in the League of Nations competition was published in Schweizerische Bauzeitung on July 30, 1927, Sigfried Giedion drew on his expertise in a commentary in the Neue Zürcher Zeitung of July 24, 1927. ${ }^{28}$ First and foremost, Giedion quoted Osswald's observation that any auditorium larger than 20,000 cubic meters created acoustic problems. How, Giedion asked, "could the feeble human voice penetrate such massive monumentality?"29 This connection between acoustics as a function and monumentality as an anti-acoustical concept remained Giedion's primary argument in favor of Le Corbusier and

\footnotetext{
${ }^{24}$ Le Corbusier: "La Salle Pleyel. Une preuve de l'évolution architecturale." Cahiers d'Art, 3, No 2, 1928, p. 89. Le Corbusier's draws his praise of calculus nevertheless into synthesis with the arts: "une oeuvre gigantesque manifestant les conquêtes de la peinture moderne et exprimant - libéré de toute tradition, - le lyrisme de l'époque." Ibid., p. 90. It is this synthesis that Christopher Pearson's analysis of the "acoustical trope" foregrounded as "the new 'biological system' of design used by Lyon in his acoustic ceiling for the Salle Pleyel in Paris." Pearson, Christopher: "Le Corbusier and the Acoustical Trope: An Investigation of Its Origins.” The Journal of the Society of Architectural Historians, 56 (June), 1997, p. 182.

25 "Response to Moscow," quoted in Cohen, Jean-Louis: Le Corbusier and the Mystique of the USSR. Theories and Projects for Moscow 1928-1936. Princeton; NJ: Princeton University Press, 1992, p. 146.

${ }^{26}$ Letter of October 31, 1931, quoted in ibid., p. 168, footnote 18; 180.

${ }^{27}$ Lyon to Le Corbusier, letter dated February 9, 1935. FLC Correspondences: LYON, GUSTAVE, 64-70: E2-9-67-001.

${ }^{28}$ Giedion, Sigfried: "Die Architektur am Wendepunkt. Anmerkungen zum Wettbewerb um das Völkerbundgebäude." Neue Zürcher Zeitung, July 24, 1927, p. 4. Giedion's article was not the first to respond to the jury report; Peter Meyer had commented on the competition results ten days earlier in Neue Zürcher Zeitung. The article is in Giedion's files.

29 "Wie soll eine schwache menschliche Stimme so viel Monumentalität durchdringen?" Ibid.
} 
Pierre Jeanneret's project, although he admitted in the Zurich newspaper that these were "precarious matters, especially as the experts of the young science of acoustics do not always agree." 30

A few months later, in his extensive article on the competition in Bauwelt of November 3, 1927, Giedion again repeated Osswald's arguments against over-large auditoriums, along with his criticism of inadequate sound quality in contemporary loudspeaker technology and the idea that auditoriums should preferably be designed with variable size. Giedion seems to have completely appropriated Osswald's knowledge as his own, and by this point no longer mentioned his name.

Of the four crucial functions that Giedion lists for the Palace of Nations in his Bauwelt article, the acoustics inside the General Assembly auditorium took the first place, followed by the organization of the offices, the circulation of traffic, and the complex's relationship to the landscape. Regarding the acoustics of the large Assembly hall, Giedion argued that any volume larger than 20,000 cubic meters would cause acoustic problems, pointing out that some architects had devised spaces of 260,000 cubic meters or prided themselves on recreating the Pantheon for the Great Assembly. According to his newly acquired expert knowledge, the 2.4 square meters for each of the 2,600 persons, as laid out in the competition brief, would need to be reduced; otherwise the result would be in a space beyond control, where "the human voice is not expected to be present." 31 He did mention the possibility of loudspeaker amplification, but discarded it immediately: "At the current moment, loudspeakers with their distortion and interference make it hopeless from the outset to believe that any such monumental ambition could be satisfied unconditionally by these means." 32

Giedion gave detailed explanations of the two projects he favored, the one by Le Corbusier and Pierre Jeanneret (awarded one out of nine ex aequo first prizes), and the one by Hannes Meyer and Hans Wittwer (awarded one out of nine second mentions). The presentation of the two was unequal, however. Expanding at length on acoustics for the first scheme, he abandoned the topic when presenting Meyer and Wittwer's project, in which the authors had decided to resolve the sound transmission issue by using loudspeakers. Instead, Giedion emphasized the auditorium design as devised by Gustave Lyon for Le Corbusier and Pierre Jeanneret, providing abundant explanations on "acoustical quality" ("Hörsamkeit") and a comparative section of the Salle Pleyel.

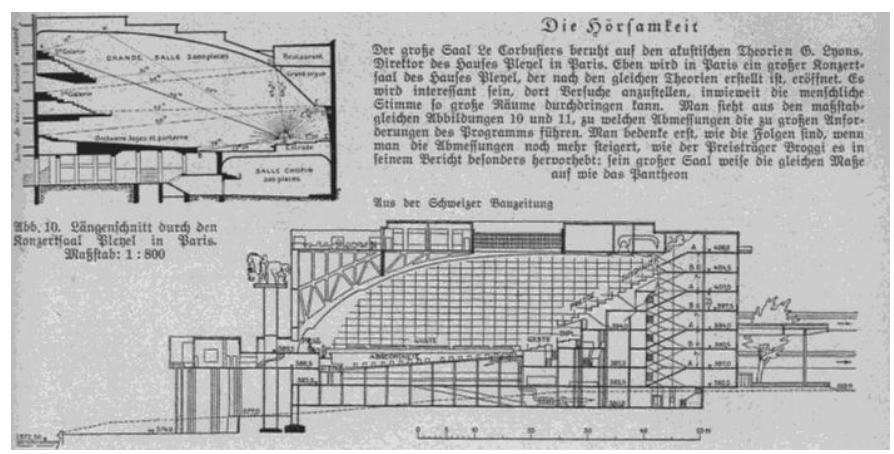

15. “Acoustical Quality” (“Hörsamkeit”) in Giedion’s expert explanation, Bauwelt, 1927.

\footnotetext{
30 "Man spürt, die Sachlage ist prekär, um so mehr als die Vertreter der immerhin noch jungen, akustischen Forschung selbst nicht ganz einer Meinung und Theorie zu sein scheinen.” Ibid.

31 "Eine menschliche Stimme hat hier nichts mehr zu suchen." Giedion, Sigfried: "Wer baut das Völkerbundgebäude?" Bauwelt, 18, № 44 (November 3), 1927, p. 1094.

32 "Bei dem heutigen Stand der Lautsprecher mit ihrer Verzerrung und Interferenz ist es von vornherein hoffnungslos, wenn man glaubt, damit bedingungslos jedem Monumentalanspruch genügen zu können.” Ibid.
} 
On the one hand, the comparison of Le Corbusier and Jeanneret's auditorium with the Salle Pleyel, both reproduced at scale 1:800, elevated the unrealized project to the level of a European cultural monument. On the other, the assembly hall for Geneva was clearly bigger than the concert hall in Paris, prompting Giedion's critical comment that "it will be interesting to test the extent to which the human voice can penetrate such large spaces." 33 Here, he no longer seems certain that the acoustics are truly feasible. The "acoustic security" invoked in Le Corbusier's own texts for the competition seems to falter; however, Giedion soon gets back on course and closes his long explications on acoustics with the remark that others have designed far larger auditoriums.

Why did the propagandists of Modern architecture not argue for loudspeaker transmission? Some of them did, but their arguments were largely ignored, as they did not serve the argument of architecture's functionality in Le Corbusier's scheme. Just two decades later, when the United Nations headquarters ${ }^{34}$ was designed and built between 1946 and 1952 in New York, loudspeakers, simultaneous interpretation booths, and radio transmission had become taken for granted as ways to ensure auditory understanding between the nations. There is no doubt that the quality of sound transmitted by loudspeaker amplification before the end of the 1930s was questionable - yet the criticism that electroacoustics lacks authenticity is still upheld today, in the age of hi-fi and wave field synthesis. In 1927, a few competition entrants were already praising the potential of large loudspeakers as "a modern invention" by which, no matter how long the conduits, the sound could be transmitted without distortion even to the outermost corners, and - something that may have sounded futuristic in the ears of a public used to loud public speaking__"speaking in a large space will be possible at a normal volume." $" 35$

Now that Osswald's critique has resurfaced from the archives and can be introduced into the historiography of the League of Nations competition, we can better understand Giedion's advocacy of acoustic quality and his reasoning regarding loudspeakers. Giedion's doubts about the acoustic performance of Le Corbusier's "acoustically perfect" scheme are, we may speculate, expressed in a handwritten note on the last page of his own offprint of Osswald's Schweizerische Bauzeitung article: "2,700 persons: this means: the world is watching" ("2700 Personen: das heisst: die Welt ist Zuschauer"). ${ }^{36}$ Whether intended or not, the idea that the world is watching, and not listening, leaves the problem of acoustics unresolved. While the literal "understanding"- that is, hearing - of words in the auditorium of the Great Assembly was the crucial argument for some of the Modernist actors presented here, all of them seemed to have recognized the impossibility of a solution that would deliver what one could fairly call "acoustical quality."

In a long and irritated letter dated October 2, 1927, Richard Neutra, who had submitted unsuccessfully with Rudolph Schindler, ${ }^{37}$ went as far as to conclude that acoustics were not a real concern for the hall for the General Assembly because the "entire representational fall session of the League of Nations is undoubtedly rather

\footnotetext{
33 "Versuche anzustellen, inwieweit die menschliche Stimme so grosse Räume durchdringen kann." Ibid.

${ }^{34}$ See Touloumi, Olga: “Architectures of Global Communication, 1941-1970.” PhD thesis, Harvard University, 2014.

35 "Ein moderner, mit neuen Erfindungen versehener Großlautsprecher bietet den Vorzug, durch verteilte Lautsprecher bei vollkommener Gleichgültigkeit der Leitungslängen, auch die äußersten Stellen, wie Lagen, Ecken u.s.w. ohne Reflexwirkung verzerrungsfrei zu besprechen. Der Redner braucht nur mit normaler Lautstärke zu sprechen und wird bei Verwendung von mehreren Mikrophonen in seiner Bewegungsfreiheit nicht beeinträchtigt.” ETH Zürich, gta archives: Nachlass Karl Moser, Hängeregister Wettbewerb Völkerbundspalast, Projektbeschrieb Distel \& Grubitz. 27.

${ }^{36}$ Osswald, Franz M.: "Zum Problem der Akustik im grossen Versammlungs-Saal des Völkerbund-Gebäudes in Genf." Schweizerische Bauzeitung, 90, № 5 (July 30), 1927. Annotated offprint in the Sigfried Giedion papers. Osswald's publication is held in several library collections, and in the Karl Moser papers, all at ETH Zürich, gta archives.

${ }^{37}$ Neutra and Schindler entered the competition in cooperation with the Austrian Institut für Auslandbeziehungen. See Hines, Thomas: Richard Neutra and the Search for Modern Architecture. New York, Oxford: Oxford University Press, 1982, p. 7.
} 
theatrical and in practice is virtually unnecessary. ${ }^{, 38}$ In defense of his own project, Neutra meticulously corrected Osswald's description and schematic drawings in Schweizerische Bauzeitung.

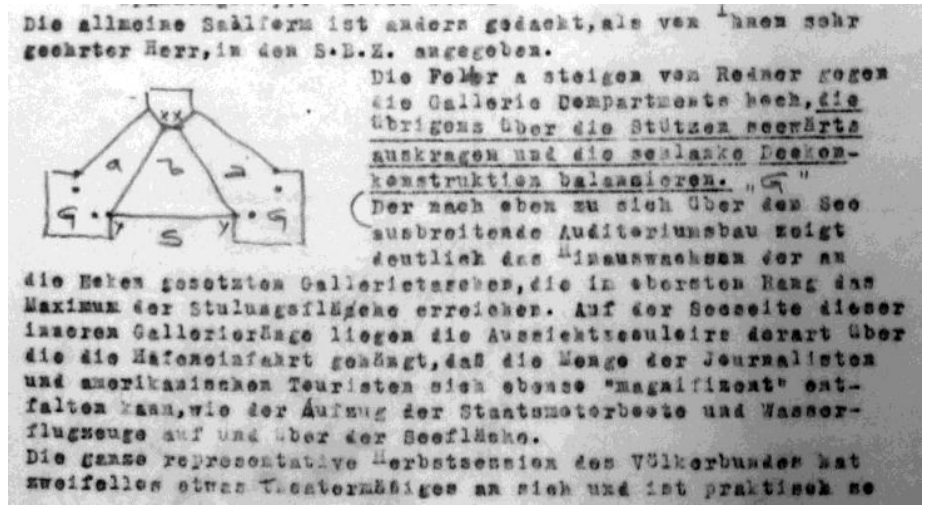

16. Detail from Neutra's letter.

In Osswald's 1928 article in The American Architect, Neutra and Schindler's project was the only one to be named and completely redrawn. Whereas in 1927 he had noted in capital letters that there were no galleries (which he considered essential for reducing the volume of the assembly space), the sketch in the 1928 publication showed Neutra and Schindler's scheme featuring four corner galleries and one rear central gallery. These served as the fourth example of auditorium plans and sections, in the top right-hand corner of the first page of Osswald's analysis of several dozen of the 377 projects, in which he discussed typical solutions and common errors.
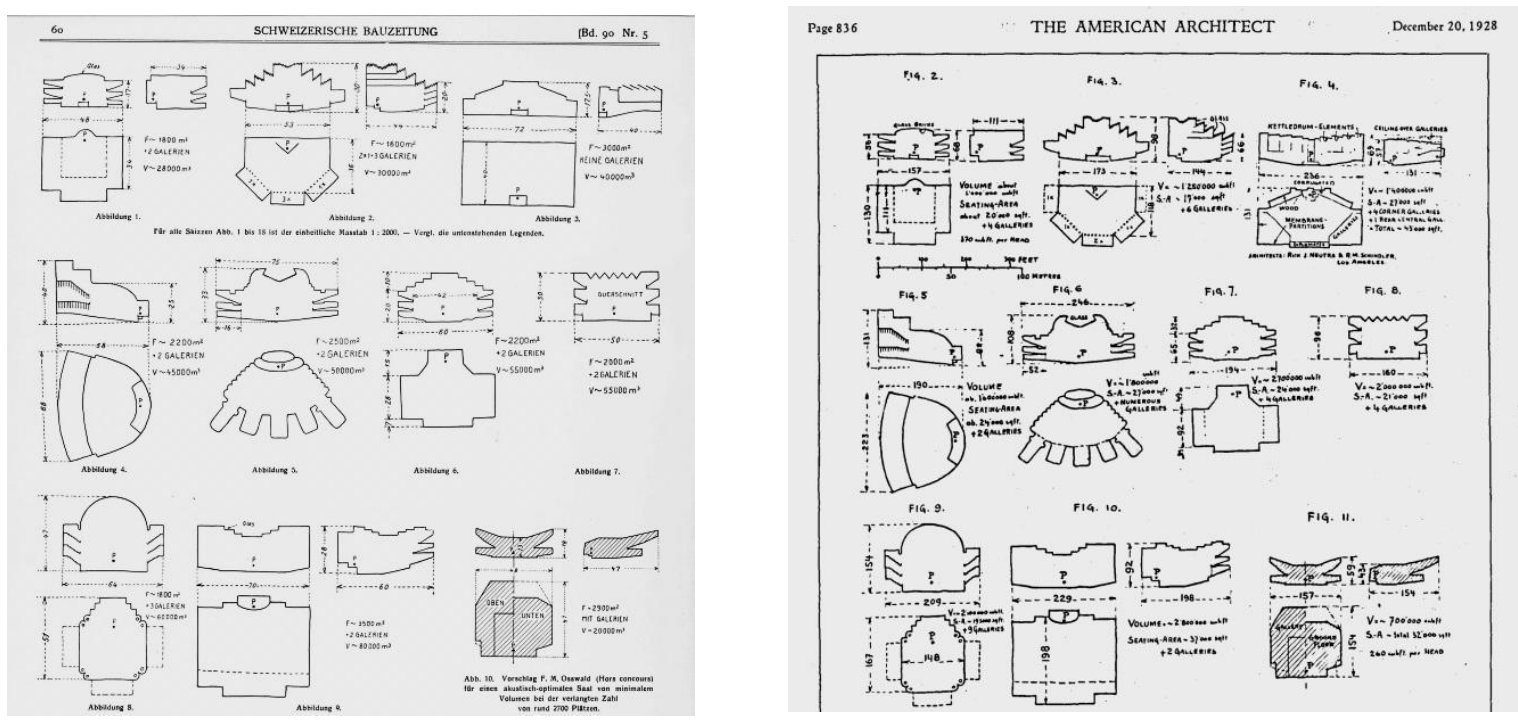

17 - 18. Franz M. Osswald's schematic plans and sections demonstrating acoustically misconceived auditoriums in Schweizerische Bauzeitung (Fig. 17) and The American Architect (Fig. 18), with Richard Neutra's scheme on the top right.

38 "Die ganze repräsentative Herbstsession des Völkerbundes hat zweifelsohne etwas Theatermässiges an sich und ist praktisch so gut wie unnötig." ETH Zürich, gta archives: 43-K(DD)-1927-10-02, pp. 2-3.The unsigned letter responds to the author of the wrongful representations of plans and sections of Neutra's scheme in Schweizerische Bauzeitung and is now part of Giedion's archive. My thanks to Daniel Weiss, who pointed out that the typeface indicates Richard Neutra as the probable letter-writer. 
The League of Nations assembly hall had to serve the purposes of international understanding in the political sense, and in the literal sense of understanding the words spoken, for nearly 2,700 people. This had no precedent in any tradition of indoor building. "2,700 persons: this means: the world is watching," we can speculate further, anticipated telecommunication networks. And yet Giedion insisted that the large Assembly Hall was a physical space of the analogue, an auditorium according to the principles of the lecture halls with which he was familiar; only under these conditions could Le Corbusier and Pierre Jeanneret's Modern project be presented as more apt, more feasible, and ultimately more functional than other projects - as a Modern solution superior to traditional forms of architectures of representation.

Remarks such as Giedion's on the world watching, or Neutra's remark on theatrical ritual in which acoustics are of no importance, raise questions not only on the visuality and aurality of architecture, but fundamentally on modern argumentation concerning functionality. In 1928, in Une maison-un palais, Le Corbusier elucidated the large Assembly Halls's acoustics, lighting, and ventilation in a 28-page chapter: "Une salle pour 2,600 personnes, organe de visibilité et d'audition." 39 In 1930, in Précisions, the chapter on acoustics ${ }^{40}$ is abbreviated, but illustrated with two pages of drawings, which are shown with the original red highlighting of the sound reflections. Also in red are the words "pas d'onde retardée," the core concept of Gustave Lyon's principle for auditorium acoustics. ${ }^{41}$
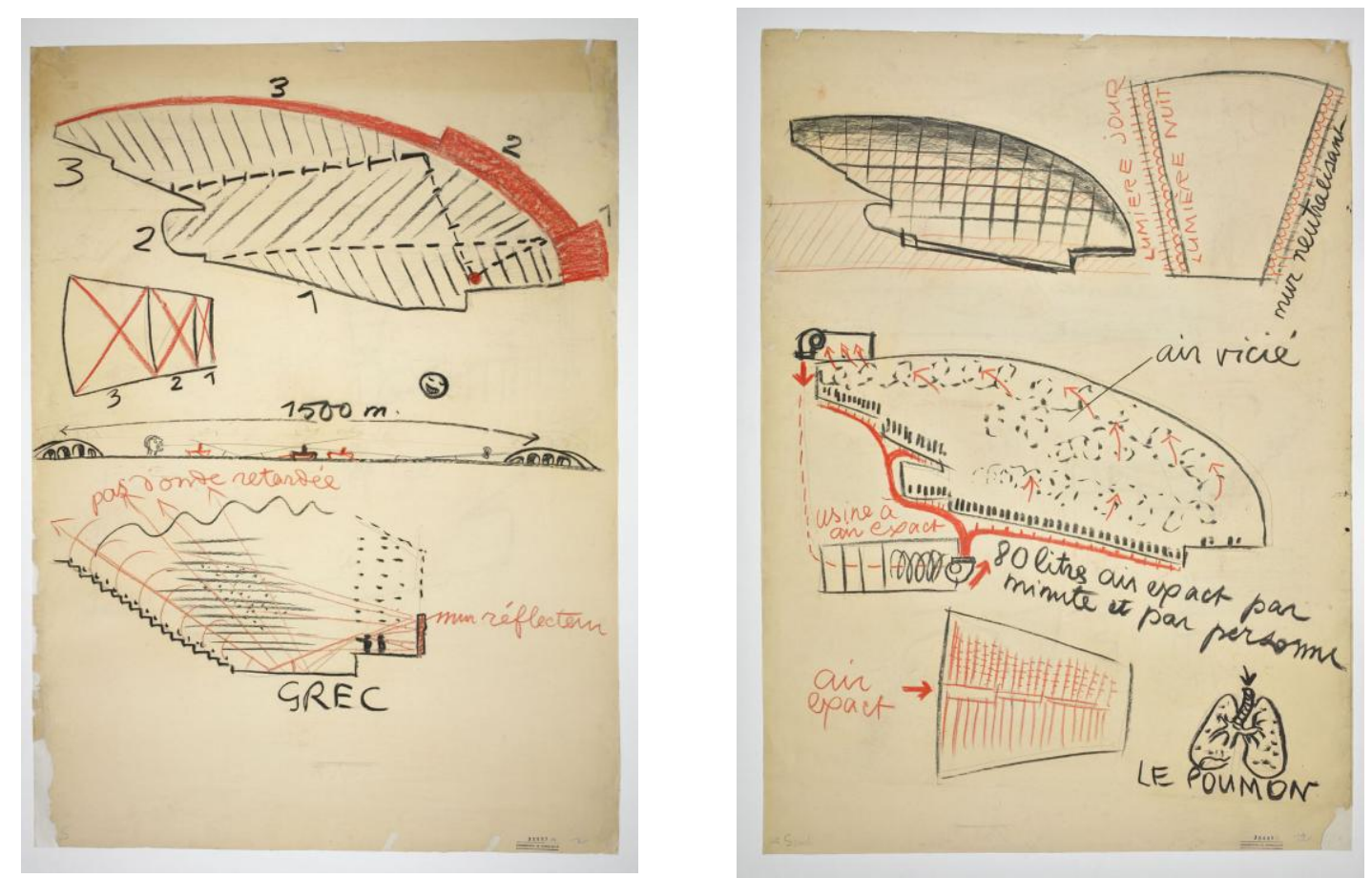

19 - 20. Explications on acoustics, lighting and ventilation for Précisions (archival drawings).

\footnotetext{
${ }^{39}$ Le Corbusier: Une maison—un palais. À la recherche d'une unité architecturale. Crès, Paris: Collection de l'Esprit nouveau, 1928, pp. 106-133.

${ }^{40}$ Le Corbusier: Précisions. Sur un état présent de l'architecture et de l'urbanisme. Crès, Paris: Collection de l'Esprit nouveau, 1930, pp. 158-164.

${ }^{41}$ FLC 33507A; 33495B.
} 
Reproduced in Précisions in black and white with long explanations, ${ }^{42}$ these drawings are based on Lyon's theory. While acousticians in 1927 embraced loudspeaker technology, albeit hesitantly, as a potential, architects in 1930 still enforced the idea that the problem had to be resolved by the architecture itself, by the sound reflections coming from the walls and the ceiling. "Understanding each other by means of the ear" (in other words, without electroacoustic assistance), Le Corbusier wrote, was the only way to a true understanding. The problem was one of the senses: "de l'oeil et de l'oreille: visibilité et acoustique, dans un lien où l'on réunit comme en une véritable Tour de Babel, les gens de tous le pays et de toutes les langues, en des débats dont l'enjeu est la paix du monde. S'entendre des oreilles est le seul chemin que peut prendre le coeur ou la raison." ${ }^{23}$

Le Corbusier's interest in acoustics was programmatic in that acoustics was a modern science; it was not limited to the technological, but also embraced the psychological and physiological. On the fourteenth of the competition panels, with a bird's-eye rendering of the entire complex and four perspective sketches of the General Assembly's exterior and interior, the lobby, and the roof garden, the words collaged next to the sketches are remarkable: the Great Assembly is described as the "heart" (next to the exterior view) and as the "throat," the "eardrum," and a "vessel of light" ${ }^{44}$ (next to the interior view). In the Modernist rhetoric around the League of Nations competition, it was clearly the technological aspect of acoustics that was instrumentalized in the claims that a project was feasible, functional, and forward-looking.

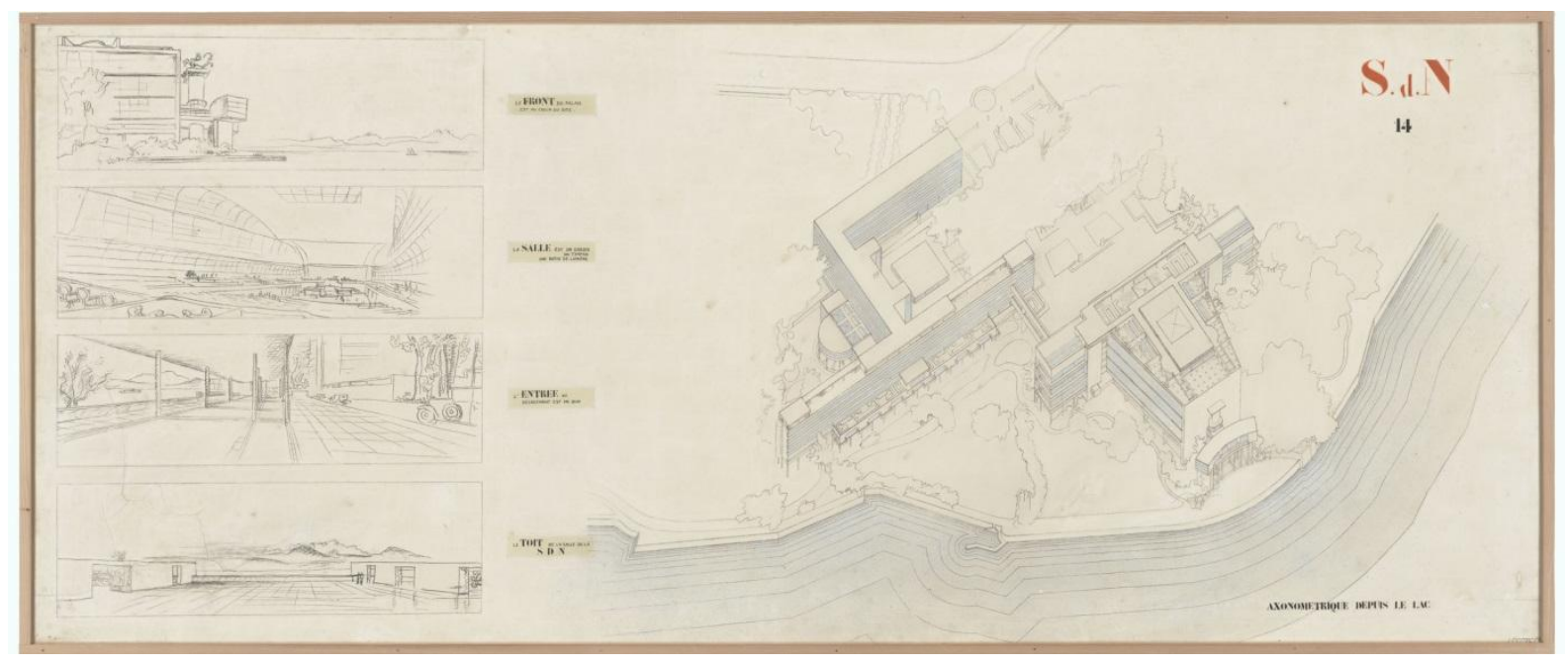

21. "Le front du palais est au coeur du site"; "La Salle est un gosier, un tympan, une boîte de lumière." Le Corbusier and Pierre Jeanneret's competition panel 14.

\section{Conclusion: Acoustics as a Function in Architecture}

The conjunction of the League of Nations competition with the formation of architectural acoustics as a professional and academic discipline set the scene for the prevalence of acoustics in the discourses surrounding Le Corbusier and Pierre Jeanneret's competition entry. When speaking in favor of Le Corbusier and Pierre Jeanneret's scheme, Franz Max Osswald and Gustave Lyon, Peter Meyer and Sigried Giedion all foregrounded the acoustical quality ("Hörsamkeit," as Giedion introduced it to his readers in Bauwelt in 1927). Le Corbusier

\footnotetext{
${ }^{42}$ Le Corbusier: Précisions. Crès, Paris: Collection de l'Esprit nouveau, 1930.

${ }^{43}$ Ibid., pp. 159, 164 (text interrupted by illustrations).

44 "La Salle est un gosier, un tympan, une boîte de lumière.” ETH Zürich, gta archives: Völkerbundpalast, Le Corbusier, 18501-14.1.
} 
himself described the Palace of Nations as a building with an "acoustically perfect Assembly Hall" for not only the administrators, but also the vast number of nearly 2,700 speakers and listeners "to work in." But while they emphasize acoustics as a fundamental function in architecture, the actors in the debates over the competition's outcome pick and choose from modern science. The programmatic exclusion of electroacoustic technologies in Meyer's and Giedion's lines of argument demonstrates that the young science of acoustics was consulted only selectively, and was instrumentalized in claims to be Modern without any further interest in a technological future-which in terms of electroacoustic communication was still decades away. The first fall session in the Palace of the League of Nations was held in September 1937, in an Assembly Hall of approximately 19,000 cubic meters and 1,540 seats, thus considerably smaller than the size given in the competition brief, and initially without loudspeaker equipment. ${ }^{45}$

The episodes of debate over its acoustics in the years from 1927 to 1930, which I have outlined in this paper, suggest that function is a performance projected onto architectural programs. History will resound in a different timbre if we understand function anew: as program, as projection, and as performance. Acoustics, and this is my argument, gives us the opportunity to revisit the history of the League of Nations competition and of 1920s architectural discourses. Without listening, there can be no understanding.

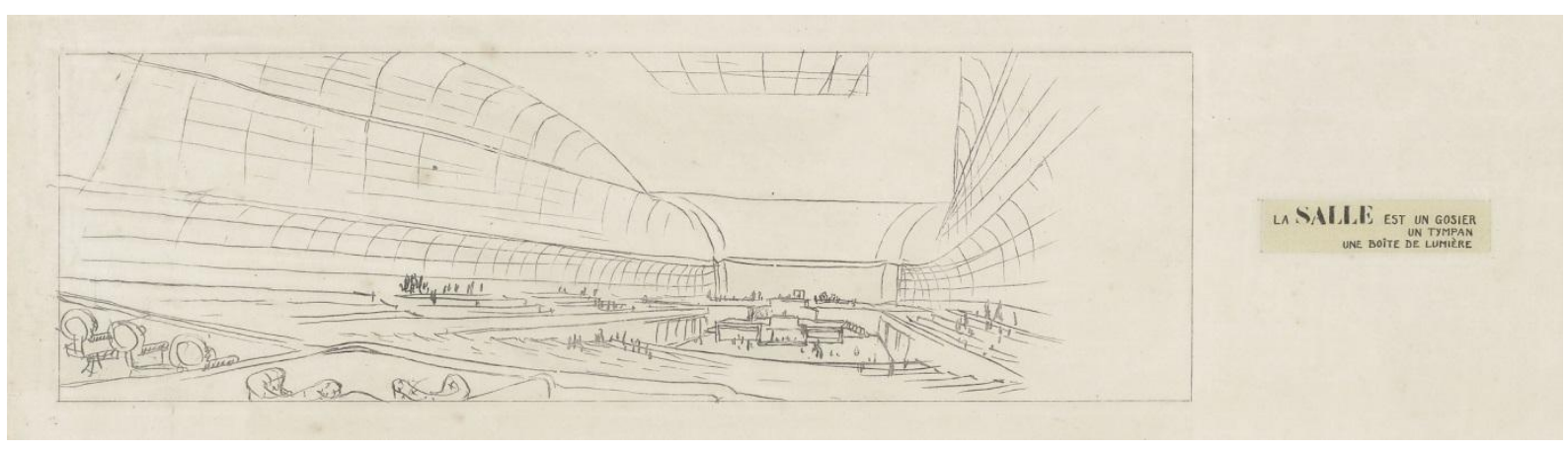

22. Le Corbusier and Pierre Jeanneret's competition panel 14, detail.

\section{Acknowledgments}

This paper was developed from research conducted for my dissertation "Hellhörige Häuser. Akustik als Funktion der Architektur. 1920-1970" ("Proof of Sound. Acoustics as a Function of Architecture, 1920-1970"), an investigation into the conjunction and interdependency of the modern science of applied acoustics and architectural problems in the first half of the twentieth century.

I would like to thank Prof. Laurent Stalder and Prof. David Gugerli of E.T.H. Zurich, as well as Ing. Kurt Eggenschwiler of Empa for their astute advice during the writing of the doctoral thesis on which this paper is based, and Kate Sturge of the Max Planck Institute for the History of Science in Berlin for her help in editing this first English text on the debates on acoustics at the League of Nations.

\section{List of illustrations}

Figs. 1 and 18: Osswald, Franz M.: "The Acoustics of the Large Assembly Hall of the League of Nations, at Geneva, Switzerland.” The American Architect, 84, № 2559 (December 20), 1928. p. 838; p. 836.

\footnotetext{
${ }^{45}$ Chéronet, Louis: Le Palais des la SDN. Paris: L'Illustration, 1938, p. 64 (ETH library copy from the private library of Franz Max Osswald).
} 
Figs. 2, 12, 14, 19, and 20: Archives Fondation Le Corbusier (FLC), Paris: Palais de la Sociéte des Nations, Genève, 1927: I2-1-59-001; I2-I-78-001; Correspondances: Lyon, Gustave (64-70): Correspondances avec L.C. 26/08/1927-09/02/1935: E2-9-64-001; Précisions, 33507A; 33495B. All: CFLC-ADAGP.

Figs. 3, 8, 9, 21, and 22: gta Archiv, Institut für Geschichte und Theorie der Architektur, ETH Zürich: 185-10, Völkerbundpalast, Le Corbusier, 100-01-10; 100-01-14; 100-01-18. All: CFLC-ADAGP.

Figs. 4 and 17: Osswald, Franz M.: "Zum Problem der Akustik im grossen Versammlungs-Saal des VölkerbundGebäudes in Genf." Schweizerische Bauzeitung, 90, Nº 5 (July 30), 1927. p. 62; p. 60.

Figs. 5, 6, and 7: Database of "Epistemes of Modern Acoustics" project under the direction of Prof. Viktoria Tkaczyk, Max Planck Institute for the History of Science, Berlin (under construction, online 2016).

Figs. 10 and 11: Boyer, Guy: La salle Pleyel. Ed. Alain Metternich. Paris: Connaissance des arts, 2006, p. 14; p. 16.

Fig. 13: Centre Canadien d'Architecture / Canadian Centre for Architecture, Montréal, CCA Collection DR1985:0625: Le Corbusier. Concept diagrams in longitudinal section and plan of the acoustical, lighting, and air circulation systems for the Great Hall of the Palace of the League of Nations, Geneva, Switzerland, December 1929. Pen and ink, 27.0 x $21.1 \mathrm{~cm}$. CFLC-ADAGP.

Fig. 15: Giedion, Sigfried: “Wer baut das Völkerbundgebäude?” Bauwelt, 18, № 44 (November 3), 1927. p. 1097.

Fig. 18: gta Archiv, Institut für Geschichte und Theorie der Architektur, ETH Zürich: 43-K(DD)-1927-10-02, Nachlass Sigfried Giedion, Korrespondenz.

\section{Bibliography}

Amundsen, M.M. and others: "Manifestation des savants, des industriels, des poètes, des financiers en faveur du projet le Corbusier et Pierre Jeanneret." Cahiers d'Art, 3, № 2, 1928. pp. 87-88.

Behne, Adolf: Der moderne Zweckbau. Munich: Drei Masken, 1926.

Chéronet, Louis: Le Palais des la SDN. Paris: L’Illustration, 1938.

Cohen, Jean-Louis: Le Corbusier and the Mystique of the USSR. Theories and Projects for Moscow 1928-1936. Princeton, NJ: Princeton University Press, 1992.

Le Corbusier: “Acoustique: Une conquête de la technique moderne.” L'Intransigeant, October 15, 1927. pp. 1.

Le Corbusier: “La Salle Pleyel. Une preuve de l'évolution architecturale.” Cahiers d'Art, 3, № 2, 1928. pp. 89-90.

Le Corbusier: Une maison-un palais. À la recherche d'une unité architecturale. Crès, Paris: Collection de l'Esprit nouveau, 1928.

Le Corbusier: Précisions. Sur un état présent de l'architecture et de l'urbanisme. Crès, Paris: Collection de l'Esprit nouveau, 1930.

Le Corbusier: Le Corbusier et Pierre Jeanneret. Euvre Complète de 1910-1929. Zurich: Girsberger, 1937.

Le Corbusier: Palais de la Société des Nations, Villa les terrasses, and other buildings and projects, $1926-1927$. New York: Garland; Paris: Fondation Le Corbusier, 1982.

Fischer, Sabine von. Das akustische Argument. Neue Parameter in der Architektur des 20. Jahrhunderts. Zurich: gta Verlag (in preparation).

von Fischer, Sabine: “A Visual Imprint of Moving Air” (in preparation).

Förster, Kim: The Institute for Architecture and Urban Studies (1967-85). Zurich: gta Verlag (in preparation).

Frampton, Kenneth: “Le Corbusier and 'l'Esprit Nouveau."” Oppositions, No 15/16 (Winter/Spring), 1979. pp. $13-58$. 
Giedion, Sigfried: "Die Architektur am Wendepunkt. Anmerkungen zum Wettbewerb um das Völkerbundgebäude.” Neue Zürcher Zeitung, July 24, 1927. p. 4.

Giedion, Sigfried: “Wer baut das Völkerbundgebäude?” Bauwelt, 18, № 44 (November 3), 1927. pp. $1093-1098$.

Gubler, Jacques; Quincerot, Richard: “Da Maratona a Ginevra.” Parametro, No 140 (October), 1985. pp. $24-31$.

Hines, Thomas S.: Richard Neutra and the Search for Modern Architecture. New York, Oxford: Oxford University Press, 1982.

Meyer, Peter; Le Corbusier: “Internationaler Wettbewerb für das Völkerbund-Gebäude in Genf.” Schweizerische Bauzeitung, 90, № 2 (July 9), 1927. pp. 13-20.

Moos, Stanislaus von: Le Corbusier. Elemente einer Synthese. Frauenfeld: Huber, 1968.

Oechslin, Werner; Roth, Alfred: Le Corbusier \& Pierre Jeanneret: Das Wettbewerbsprojekt für den Völkerbundspalast in Genf 1927: à la recherche d'une unité architecturale. Zurich: gta Verlag, 1988.

Osswald, Franz M.: “Zum Problem der Akustik im grossen Versammlungs-Saal des Völkerbund-Gebäudes in Genf." Schweizerische Bauzeitung, 90, № 5 (July 30), 1927. pp. 59-66.

Osswald, Franz M.: "The Acoustics of the Large Assembly Hall of the League of Nations, at Geneva, Switzerland," The American Architect, 84, No 2559 (December 20), 1928. pp. 833-842.

Osswald, Franz M.: Schall und Raum. Antrittsrede an der Eidgenössischen Technischen Hochschule in Zürich, 29. Juni 1929. Zurich: E.T.H., 1929.

Osswald, Franz M.: “Akustisch hochwertige Parabelsäle.” Schweizerische Bauzeitung, 95, No 4, 1930. pp. 47-51.

Osswald, Franz M.: “Akustischer Konzert- und Vortragsaal mit veränderlichem Volumen.” Schweizerische Bauzeitung, 96, № 18 (November 1), 1930. pp. 224-225.

Osswald, Franz M.: "Raumakustik in geometrischer Betrachtung." Zeitschrift für technische Physik, 17, № 12, 1936. pp. 561-563.

Osswald, Franz M.: “Zur akustischen Gestaltung von Grossräumen.” In 100 Jahre S.I.A Festausgabe der SBZ zur Jahrhundertfeier. Zurich: Jegher, 1937. pp. 66-70.

Pallas, Jean-Claude: Histoire et architecture du Palais des Nations (1924-2001). L'Art déco au service des relations internationales. Geneva: Nations Unies, 2001.

Pearson, Christopher: "Le Corbusier and the Acoustical Trope: An Investigation of Its Origins." The Journal of the Society of Architectural Historians, 56 (June), 1997. pp. 168-183.

Ritter, John: "World Parliament. The League of Nations Competition, 1926." Architectural Review, No 136 (July), 1964. pp. 17-23.

Sabine, Wallace C.: “Theatre Acoustics.” The American Architect, 104, No 1984, 1913. pp. 256-278.

Sabine, Wallace C.: Collected Papers on Acoustics. Cambridge, MA: Harvard University Press, 1922.

Thompson, Emily: The Soundscape of Modernity. Architectural Acoustics and the Culture of Listening in America, 1900-1933. Cambridge, MA: MIT Press, 2002.

Touloumi, Olga. "Architectures of Global Communication, 1941-1970." PhD thesis, Harvard University, Graduate School of Design, 2014.

Trendelenburg, Ferdinand: "Über Bau und Anwendung von Grosslautsprechern." Elektrotechnische Zeitschrift, 48, 1927, p. 1685-1691. 